\title{
ANALISIS KINERJA TENAGA PELAKSANA GIZI PUSKESMAS DALAM PENANGGULANGAN BALITA GIZI BURUK DI KABUPATEN KEBUMEN
}

\author{
Sudikno', Tetra Fajarwati ${ }^{1}$, Rika Rachmawati', Irlina Raswanti ${ }^{1}$, dan Sandjaja ${ }^{1}$ \\ ${ }^{1}$ Puslitbang Gizi dan Makanan, Depkes RI, Bogor
}

\section{ABSTRACT \\ WORK PERFORMANCE OF PUSKESMAS NUTRITION OFFICER IN THE MANAGEMENT OF SEVERE MALNUTRITION IN KEBUMEN}

\begin{abstract}
Ministry of Health published Guidelines for the Management of Severe Malnutrition in Puskesmas (Community Health Center) adopted from WHO book. It is a handbook for nutrition officer in Puskesmas to treat severe malnourished children in his areas. However, there has no study to evaluate work performance of nutrition officer in the implementation of the guidelines. A crosssectional study was conducted in the District of Kebumen, Central Java Province where severe malnourished children were high to determine work performance of Puskesmas nutrition officer. Samples of the study were 33 nutritition officers of Puskemas and 29 heads of Puskemas. Variables collected were characteristics of nutrition officer, budget and time allocated for nutrition, nutrition equipment and supplies, and management of severe malnutrition program; planning, implementation, monitoring, supervision, recording, reporting and evaluation constructed in questionares. A composite of good and no good were based on variables to measure work performance. The study team interviewed the samples by using questionaires. The sudy revealed that $48.5 \%$ nutrition officer had good working performance. Analysis showed that good working performance of nutrition officers in the management of severe malnutrition was associated significantly with availability of nutrition equipment and supplies in Puskesmas and Posyandu (integrated health post) and intensive supervision from District Health Office.
\end{abstract}

Keywords: severe malnutrition, work performance, nutrition officer

\section{PENDAHULUAN}

$\longrightarrow$ usat Kesehatan Masyarakat (Puskesmas) adalah sarana kesehatan terdepan yang memberi pelayanan kesehatan termasuk gizi kepada masyarakat di seluruh pelosok tanah air. Di tingkat Puskesmas upaya perbaikan gizi masyarakat dilaksanakan oleh tenaga puskesmas, seperti: Ahli Gizi, Pembantu Ahli Gizi, bidan, perawat, dan tenaga kesehatan lainnya ${ }^{(1)}$. Profil Indonesia 2002 mengungkapkan rasio ahli gizi per 100.000 penduduk adalah 3,22 orang $^{(2)}$ lebih rendah daripada perkiraan tahun 2001, yaitu sebesar 6,6 ahli gizi per 100.000 penduduk ${ }^{(3)}$. Target yang akan dicapai pada tahun 2010 adalah 22 ahli gizi per 100.000 penduduk $^{(2)}$. Di samping dari jumlah yang belum mencukupi, juga penyebarannya belum merata, sehingga belum dapat menangani masalah gizi yang ada. Kelemahan yang lain adalah rendahnya tingkat kinerja atau produktivitas serta masalah manajemen tenaga kesehatan lainnya ${ }^{(4)}$.

Menurut Brotowasisto(3), timbulnya kasus gizi buruk akhir-akhir ini memberikan gambaran tentang masih lemahnya kinerja sistem kesehatan, dalam hal ini kinerja tenaga kesehatan. Hasil penelitian kinerja petugas gizi di DKI Jakarta tahun 2001 menunjukkan bahwa 51,1 persen petugas mempunyai kinerja yang buruk $^{(5)}$. Jika demikian halnya bagaimana kinerja petugas gizi di pedesaan? 
Sebagaimana diketahui bahwa akibat krisis ekonomi sejak pertengahan tahun 1997, prevalensi KEP pada anak golongan prasekolah meningkat dari 24,8 persen pada tahun 2000 menjadi 27,3 persen pada tahun $2003^{(6)}$. Balita gizi kurang menurut kabupaten di Indonesia tahun 2003 sejumlah 2-4 dari 10 balita di 72 persen kabupaten ${ }^{(7)}$. Data SKRT (2004) memberikan prevalensi gizi kurang (BB/U) pada balita sebesar 19 persen dan prevalensi gizi buruk sebesar 3 persen. Sedangkan status gizi (BB/TB) menunjukkan prevalensi balita kurus sebesar 8 persen dan prevalensi kurus sekali 2 persen ${ }^{(8)}$. Menurut Profil Indonesia $2002^{(9)}$, persentase status gizi buruk (BB/U) di Jawa Tengah sebesar 6,13 persen dan gizi kurang sebesar 18,2 persen. Data gizi buruk yang dikumpulkan dari kegiatan pelacakan, perawatan dan rujukan gizi buruk di Jawa Tengah menunjukkan belum adanya perbaikan status gizi secara optimal. Pada akhir tahun 1997 jumlah kasus balita gizi buruk ditemukan 2.778 anak, dan sampai akhir 2002 terdapat penambahan kasus baru sebanyak 6.172 anak. Setelah dilakukan intervensi, sejumlah 5.423 anak mengalami perbaikan, 182 anak meninggal. Selanjutnya pada tahun 2003 ditemukan 4.555 anak dengan gizi buruk. Hasil Pemantauan Status Gizi Jawa Tengah menunjukkan angka prevalensi gizi buruk sebesar 1,36 persen lebih tinggi dari tahun 2002, yaitu 1,32 persen ${ }^{(10)}$. Kabupaten Kebumen merupakan salah satu wilayah di Jawa Tengah dengan jumlah gizi buruk yang cukup tinggi, di samping daerah lain, seperti: Grobogan, Pekalongan, Rembang, Blora, dan Tegal ${ }^{(11)}$. Pada tahun 2002 diketahui sejumlah 250 balita mengalami gizi buruk ${ }^{(11)}$. Jumlah ini mengalami peningkatan pada tahun 2003 yaitu sejumlah 398 balita $^{(12)}$. Kemudian pada tahun 2005 sampai dengan bulan Juni ditemukan 491 kasus balita gizi buruk dan 1.516 balita dengan gizi kurang ${ }^{(13)}$. Keadaan ini tentunya perlu ditanggulangi secara terpadu, baik lintas program maupun lintas sektor di daerah.

Tenaga pelaksana gizi puskesmas merupakan salah satu tenaga lapangan yang langsung menghadapi masyarakat, termasuk dalam penanganan balita gizi buruk di wilayah kerjanya. Tugas pokok tenaga pelaksana gizi meliputi: penentuan prioritas masalah, merencanakan, melaksanakan dan melaporkan kegiatan-kegiatan dalam menanggulangi masalah gizi ${ }^{(1)}$. Dalam studi ini hanya akan membahas permasalahan kinerja tenaga pelaksana gizi puskesmas dalam penanggulangan masalah balita gizi buruk di wilayah puskesmas dengan mengacu pada Buku Pedoman Kerja Tenaga Gizi Puskesmas Tahun 1995 dan Buku Pedoman Tata Laksana Kurang Energi Protein pada Anak di Puskesmas dan di Rumah Tangga yang sudah disosialisasikan oleh Departemen Kesehatan pada tahun $1999^{(14)}$.

\section{Tujuan}

Tujuan penelitian adalah:

- Meneliti gambaran kinerja tenaga pelaksana gizi puskesmas.

- Meneliti faktor-faktor yang berpengaruh terhadap kinerja tenaga pelaksana gizi puskesmas dalam penanggulangan balita gizi buruk.

\section{BAHAN DAN CARA}

Penelitian ini merupakan studi evaluatif terhadap kegiatan program gizi yang dilakukan tenaga pelaksana gizi puskesmas di Kabupaten Kebumen, Provinsi Jawa Tengah, khususnya dalam penanggulangan balita gizi buruk dengan menggunakan rancangan penelitian potong lintang. Populasi adalah semua tenaga pelaksana gizi Puskesmas di Kabupaten Kebumen Propinsi Jawa Tengah, dan sampel adalah seluruh tenaga pelaksana gizi puskesmas di wilayah kabupaten Kebumen dengan masa kerja minimal satu tahun dan menjadi penanggungjawab program gizi puskesmas minimal satu tahun. Pengambilan sampel dilakukan secara purposive.

Data dikumpulkan dengan cara melakukan wawancara terhadap tenaga pelaksana gizi puskesmas, yaitu meliputi: kinerja TPG dalam penanggulangan balita gizi buruk, status perkawinan, jenis kelamin, umur, pendidikan, lama bekerja, pelatihan, 
status kepegawaian, pekerjaan tambahan, sarana dan prasarana, dorongan atasan, insentif, beban kerja, tanggung jawab, waktu efektif bekerja, supervisi, dan kerjasama. Sebagai data pendukung tentang kinerja TPG juga dilakukan wawancara terhadap Kepala Puskesmas.

Pengukuran kinerja pada penelitian ini dilakukan dengan menggunakan kuesioner terstruktur yang dibuat berdasarkan tugas dan fungsi tenaga pelaksana gizi puskesmas, khususnya dalam penanggulangan balita gizi buruk berdasarkan buku Pedoman Tenaga Gizi Puskesmas ${ }^{(2)}$. Kinerja merupakan variabel komposit tentang penilaian tugas dan fungsi TPG Puskesmas yang meliputi variabel perencanaan, pelaksanaan, pelaporan, pemantauan dan evaluasi khususnya dalam penanggulangan balita gizi buruk di Puskesmas. Variabel perencanaan meliputi mekanisme perencanaan program gizi, rencana biaya program, jadwal kegiatan bulanan. Variabel pelaksanaan meliputi kegiatan pelacakan kasus gizi buruk, pengukuran antropometri, penyuluhan, PMT-Penyuluhan, PMTPemulihan, rujukan balita gizi buruk ke rumah sakit. Variabel pelaporan meliputi kegiatan analisa dan laporan kasus gizi buruk setiap bulan. Variabel pemantauan dan evaluasi meliputi kegiatan pemantauan perkembangan kasus gizi buruk setiap bulan, perkembangan balita gizi buruk pasca perawatan di rumah sakit. Kemudian untuk menilai kinerja TPG Puskesmas dilakukan skoring terhadap variabel-variabel tersebut. Selanjutnya dilakukan pengelompokan kinerja dengan menggunakan median sebagai cut-of point, sehingga variabel menjadi dikotomi (baik dan kurang). Hal ini didasarkan pada konsep tingkat kinerja personel yang dapat diterima oleh organisasi adalah kinerja di atas rata-rata ${ }^{(5)}$.

Selanjutnya data yang dikumpulkan dianalisis secara deskriptif untuk melihat gambaran kinerja TPG Puskesmas. Kemudian untuk mengetahui faktor-faktor yang berpengaruh dengan kinerja TPG dilakukan uji Kai-Kuadrat dengan derajat kemaknaan 0,05.

\section{HASIL DAN BAHASAN}

\section{Karakteristik Tenaga Pelaksana Gizi \\ Puskesmas}

Responden dalam penelitian ini sejumlah 35 TPG Puskesmas, dan yang memenuhi kriteria inklusi 33 TPG Puskesmas. Sedangkan Kepala Puskesmas yang menjadi responden adalah Kepala Puskesmas dimana TPG Puskesmas bekerja, yaitu 29 orang. Hal ini dikarenakan adanya jabatan rangkap Kepala puskesmas di empat Puskesmas.

Penelitian ini menunjukkan, dari 33 tenaga pelaksana gizi puskesmas yang diteliti, sejumlah 16 orang (48,5\%) memiliki kinerja baik dalam program penanggulangan balita gizi buruk. Hasil penelitian ini tidak jauh berbeda dengan Agustijani( ${ }^{(6)}$ yang mendapatkan tenaga pelaksana gizi di DKI Jakarta dengan kinerja baik sebesar 48,9 persen.

\section{Kinerja TPG Puskesmas dalam penanggulangan balita gizi buruk menurut faktor internal \\ Gambaran pengaruh kinerja TPG} Puskesmas dalam penanggulangan balita gizi buruk dengan faktor internal TPG secara rinci dapat dilihat pada Tabel 1. Menurut status perkawinan tampak bahwa persentase tertinggi kinerja baik TPG Puskesmas dalam penanggulangan balita gizi buruk terdapat pada TPG Puskesmas yang sudah menikah, yaitu sebesar 55,6 persen. Dari jenis kelamin persentase tertinggi kinerja baik terdapat pada TPG laki-laki, yaitu 75 persen. Kemudian menurut kelompok umur persentase tertinggi kinerja baik terdapat pada kelompok umur 35 tahun ke atas, yaitu sebesar 58,3 persen.

Selanjutnya dari pendidikan profesi responden diketahui bahwa persentase tertinggi kinerja baik TPG Puskesmas terdapat pada responden dengan pendidikan profesi gizi (SPAG maupun Akademi Gizi), yaitu sebesar 52,4 persen. Menurut lama bekerja responden diketahui bahwa persentase tertinggi kinerja baik terdapat pada TPG Puskesmas yang bekerja kurang dari lima tahun, yaitu sebesar 57,9 persen. 
Dan dari data pelatihan gizi buruk yang diselenggarakan oleh Dinas Kesehatan Kabupaten Kebumen diketahui bahwa persentase tertinggi kinerja baik terdapat pada TPG Puskesmas yang pernah mengikuti pelatihan satu kali atau lebih, yaitu sebesar 54,2 persen (Tabel 1).

Tabel 1

Distribusi Kinerja TPG Puskesmas menurut Faktor Internal

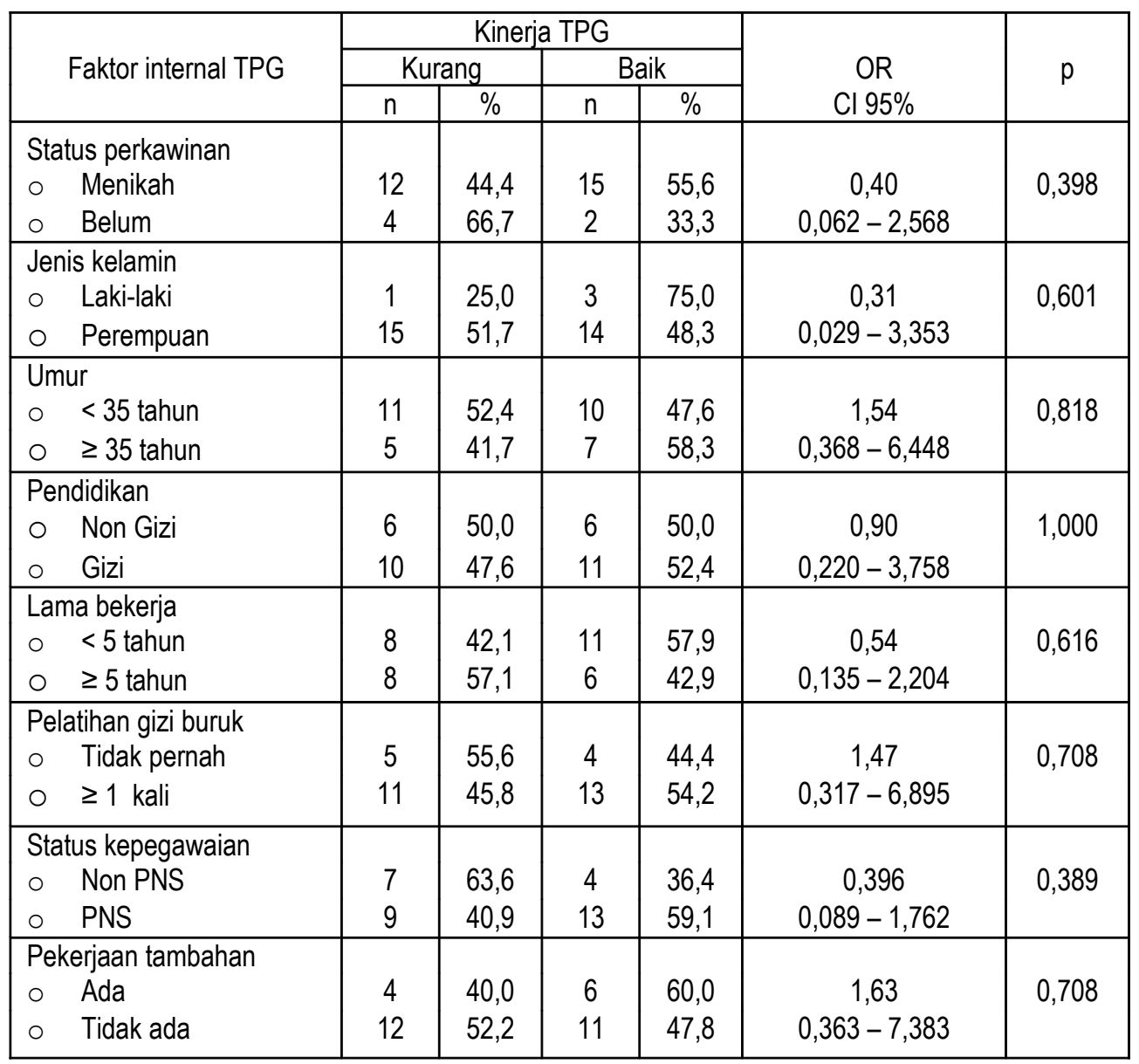

Berdasarkan status kepegawaian responden diketahui bahwa persentase tertinggi kinerja baik terdapat pada TPG Puskesmas yang sudah PNS, yaitu sebesar 59,1 persen. Sedangkan dari pekerjaan tambahan responden di rumahtangga (di luar jam bekerja) tampak bahwa persentase tertinggi kinerja baik terdapat pada TPG Puskesmas yang mempunyai pekerjaan tambahan, yaitu sebesar 60 persen (Tabel 1).
Dari hasil analisis diketahui bahwa tidak ada pengaruh bermakna antara faktor internal TPG (status perkawinan, jenis kelamin, umur, pendidikan, lama bekerja, pelatihan, status kepegawaian, dan pekerjaan tambahan) dengan kinerja TPG Puskesmas dalam penanggulangan balita gizi buruk $(p>0,05)$.

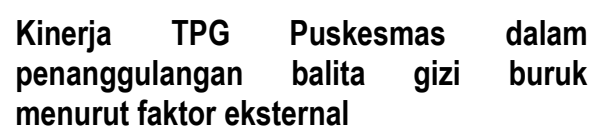


Pengaruh kinerja TPG Puskesmas dalam penanggulangan balita gizi buruk dengan faktor eksternal TPG secara rinci dapat dilihat pada Tabel 2. Menurut sarana dan prasarana tampak bahwa persentase tertinggi kinerja baik TPG Puskesmas dalam penanggulangan balita gizi buruk terdapat pada TPG Puskesmas yang memiliki sarana dan prasarana baik, yaitu sebesar 68,2 persen. Sarana dan prasarana tersebut meliputi: timbangan dacin $25 \mathrm{~kg}$, timbangan berat badan (bathroom scale), alat ukur panjang badan bayi, pita LILA, microtoise, KMS balita, formulir pelacakan gizi buruk, buku pedoman tata laksana KEP. Selanjutnya dari dorongan atasan terhadap
TPG Puskesmas dalam penanggulangan balita gizi buruk diketahui bahwa persentase kinerja baik dan kinerja kurang distribusinya terlihat hampir merata. Kemudian menurut insentif yang diterima tampak bahwa persentase tertinggi kinerja baik terdapat pada TPG Puskesmas yang tidak mendapat insentif, yaitu sebesar 58,8 persen. Insentif yang diterima oleh TPG Puskesmas sangat bervariasi baik dari segi jumlah maupun jangka waktu penerimaan di masing-masing Puskesmas. Besaran insentif yang diberikan berkisar antara Rp. 13.000,- sampai dengan Rp. 125.000,- per bulan dengan jangka waktu pemberian bervariasi dari setiap satu bulan, tiga bulan, enam bulan, dan satu tahun.

Tabel 2

Distribusi Kinerja TPG Puskesmas menurut Faktor Eksternal

\begin{tabular}{|c|c|c|c|c|c|c|}
\hline \multirow{3}{*}{ Faktor Eksternal TPG } & \multicolumn{4}{|c|}{ Kinerja TPG } & \multirow{3}{*}{$\begin{array}{c}\text { OR } \\
\text { Cl } 95 \%\end{array}$} & \multirow{3}{*}{$\mathrm{p}$} \\
\hline & \multicolumn{2}{|c|}{ Kurang } & \multicolumn{2}{|c|}{ Baik } & & \\
\hline & $\mathrm{n}$ & $\%$ & $\mathrm{n}$ & $\%$ & & \\
\hline Sarana dan prasarana & & & & & & \\
\hline ○ Kurang & 9 & 81,8 & 2 & 18,2 & 9,64 & 0,019 \\
\hline$\circ \quad$ Baik & 7 & 31,8 & 15 & 68,2 & $1,633-56,925$ & \\
\hline Dorongan atasan & & & & & & \\
\hline ○ Kurang & 9 & 47,4 & 10 & 52,6 & 0,90 & 1,000 \\
\hline ○ Baik & 7 & 50,0 & 7 & 50,0 & $0,226-3,583$ & \\
\hline Insentif & & & & & & \\
\hline ○ Tidak ada & 7 & 41,2 & 10 & 58,8 & 0,54 & 0,605 \\
\hline$\circ \quad$ Ada & 9 & 56,3 & 7 & 43,8 & $0,137-2,167$ & \\
\hline Beban kerja & & & & & & \\
\hline$\circ$ Ringan & 9 & 52,9 & 8 & 47,1 & 1,44 & 0,858 \\
\hline$\circ$ Berat & 7 & 43,8 & 9 & 56,3 & $0,367-5,704$ & \\
\hline Tanggung jawab program & & & & & & \\
\hline $\begin{array}{l}0 \\
0\end{array}$ & 9 & $\begin{array}{l}63,6 \\
109\end{array}$ & $\begin{array}{c}4 \\
13\end{array}$ & $\begin{array}{l}36,4 \\
59,1\end{array}$ & $\begin{array}{l}2,52 \\
0568-11,250\end{array}$ & 0,389 \\
\hline Whaktu ofoktif hokeria & & & & & & \\
\hline $\begin{array}{l}\text { Waktu efektif bekerja } \\
0<6 \text { jam }\end{array}$ & 14 & 5 & 10 & 417 & 49 & 0118 \\
\hline$\circ \quad \geq 6$ jam & 2 & 22.2 & 7 & 77.8 & $0,836-28,728$ & \\
\hline Supervisi & & & & & & \\
\hline ○ Kurang & 13 & 68,4 & 6 & 31,6 & 7,94 & 0,020 \\
\hline ○ Baik & 3 & 21,4 & 11 & 78,6 & $1,601-39,416$ & \\
\hline Kerjasama & & & & & & \\
\hline$\circ$ Kurang & 9 & 56,3 & 7 & 43,8 & 1,83 & 0,605 \\
\hline ○ Baik & 7 & 41,2 & 10 & 58,8 & $0,461-7,312$ & \\
\hline
\end{tabular}


Berdasarkan beban kerja responden diketahui bahwa persentase tertinggi kinerja baik terdapat pada TPG Puskesmas dengan beban kerja berat, yaitu sebesar 56,3 persen. Sedangkan menurut tanggung jawab program yang ditangani responden diketahui bahwa persentase tertinggi kinerja baik terdapat pada TPG Puskesmas yang menangani program dua atau lebih, yaitu sebesar 59,1 persen (Tabel 2). Program atau kegiatan tambahan yang ditangani oleh TPG Puskesmas antara lain: administrasi, KIA, imunisasi, KB, bidan desa, Puskesmas Pembantu (Pustu), PKM, UKS, JPKMM, Posyandu lansia, SP2TP, pendaftaran, apotik, dan bendahara.

Menurut waktu efektif bekerja tampak bahwa persentase tertinggi kinerja baik terdapat pada TPG Puskesmas yang bekerja 6 jam atau lebih sehari, yaitu sebesar 77,8 persen. Sedangkan dari kegiatan supervisi yang dilakukan oleh Dinas Kesehatan Kabupaten diketahui bahwa persentase tertinggi kinerja baik terdapat pada TPG Puskesmas yang disupervisi dengan baik, yaitu sebesar $78,6 \%$. Selanjutnya dilihat dari kemampuan kerja sama TPG Puskesmas baik lintas program maupun lintas sektor menunjukkan bahwa persentase tertinggi kinerja baik terdapat pada TPG Puskesmas yang mempunyai kemampuan kerjasama dengan baik (Tabel 2). Instansi lintas sektor yang sering terlibat kerjasama dengan TPG Puskesmas adalah PKK desa, PKK Kecamatan, dan BKKBN.

Dari hasil analisis diketahui bahwa sarana dan prasarana baik di posyandu maupun puskesmas mempunyai pengaruh bermakna dengan kinerja TPG Puskesmas dalam penanggulangan balita gizi buruk $(p=0,019)$. Selanjutnya diketahui juga adanya pengaruh bermakna antara supervisi yang dilakukan Dinas Kesehatan Kabupaten dengan kinerja TPG Puskesmas dalam penanggulangan balita gizi buruk $(p=0,02)$. Analisis lanjut menunjukkan bahwa TPG Puskesmas yang disupervisi dengan baik mempunyai risiko kinerja lebih baik sebesar 7,94 kali dibandingkan TPG Puskesmas yang kurang mendapatkan supervisi. Hal ini sesuai dengan llyas (2001) yang menyatakan bahwa variabel supervisi masih sangat penting pengaruhnya dengan kinerja individu.

\section{KESIMPULAN DAN SARAN}

\section{Kesimpulan}

1. TPG Puskesmas dengan kinerja baik dalam penanggulangan balita gizi buruk diketahui sejumlah 16 orang $(48,5 \%)$.

2. Faktor yang berpengaruh secara bermakna terhadap kinerja TPG Puskesmas dalam penanggulangan balita gizi buruk adalah sarana dan prasarana di puskesmas dan posyandu, serta supervisi yang dilakukan Dinas Kesehatan Kabupaten.

\section{Saran}

1. Perlu dilakukan pendataan ulang dan pemenuhan kelengkapan sarana dan prasarana puskesmas dan posyandu, khususnya terkait dengan penanggulangan balita gizi buruk.

2. Upaya pembinaan tenaga pelaksana gizi puskesmas melalui kegiatan supervisi hendaknya lebih difokuskan pada wilayah puskesmas dengan jumlah gizi buruk yang banyak dan puskesmas tersulit secara geografis.

\section{UCAPAN TERIMA KASIH}

Ucapan terima kasih disampaikan kepada yang terhormat Bagian Proyek Risbinkes, Kepala Puslitbang Gizi dan Makanan, Kepala Dinas Kesehatan Kabupaten Kebumen beserta jajarannya, Kepala Puskesmas dan TPG Puskesmas, dan semua pihak yang telah membantu terlaksananya penelitian ini.

\section{RUJUKAN}


1. Departemen Kesehatan RI, Pedoman Kerja Tenaga Gizi Puskesmas, Jakarta. 1995.

2. Departemen Kesehatan RI, Profil Kesehatan Indonesia 2002, Jakarta. 2004.

3. Brotowasisto, Pelayanan Kesehatan di Indonesia, Keadilan yang didambakan, Simposium Nasional II Hasil Penelitian dan Pengembangan Kesehatan, 7-8 Desember 2005, Jakarta. 2005.

4. Ilyas, Yaslis, Kinerja: Teori, Penilaian dan Penelitian, Pusat Kajian Ekonomi Kesehatan, FKMUI. 2001.

5. Agustijani, Etty, Analisis Faktor Internal dan Eksternal Yang Berhubungan dengan Kegiatan Gizi Posyandu Serta Kinerja Petugas Gizi Puskesmas Kelurahan di Propinsi DKI Jakarta Tahun 2001, Tesis, FKMUI, 2004.

6. Untoro, Rachmi. Kebijakan dan Program Gizi Anak di Indonesia saat Ini dan Masa Mendatang (disampaikan pada seminar dan lokakarya Inovasi Pangan dan Gizi untuk Optimalisasi
Tumbuh Kembang Anak), 10-11 Mei 2004. Jakarta. 2004.

7. Atmawikarta, Arum, Perencanaan Nasional Bidang Kesehatan dalam Peningkatan Status Gizi Masyarakat, Simposium Nasional II Hasil Penelitian dan Pengembangan Kesehatan, 7-8 Desember 2005, Jakarta. 2005.

8. Sumantri, Suharsono, Tantangan Sistem Kesehatan: Akses Kualitas dan Kinerja Kesehatan (Data Surkesnas), Simposium Nasional II Hasil Penelitian dan Pengembangan Kesehatan, 7-8 Desember 2005, Jakarta. 2005.

9. Departemen Kesehatan RI, Lampiran Profil Kesehatan Indonesia 2002, Jakarta. 2003.

10. http://dinkesjateng.go.id, Profil Kesehatan 2003. 2003.

11. http://suaramerdeka.com, Balita gizi buruk. 2002.

12. http://suaramerdeka.com, 30 Juni 2005 , Penanganan gizi buruk. 2005.

13. http://dinkes.kebumen. go.id, 21 Juni 2005, Tangani gizi buruk. 2005.

14. Departemen Kesehatan RI, Pedoman Tata Laksana Kurang Energi Protein pada Anak di Puskesmas dan di Rumah tangga, Jakarta. 1999. 